by improved economic conditions or by the new arrangements made under the Education Act of 1944. A series of studies recently published by Dr. Floud $^{8}$ and her colleagues shows that the grosser material handicaps appear to have been lessened and in many areas eliminated, but that the problem of social wastage is as yet by no means overcome.

The whole issue is of such far-reaching social im. portance that there is a most urgent need for more research. Since school investigations undertaken by outsiders are bound to be incomplete, it is to be hoped that once again the more progressive local education authorities will allow their official psychologists time and full facilities for such inquiries. But the under- lying processes are so complex and obscure that the psychogenetics of man is not likely to make much headway without carefully controlled experiments on the nature and transmission of intelligence in lower animals.

1 Bingham, W. "Aptitudes and Aptitude Testing" (Houghton Mifflin Co., 1937), “

2 Galton, F., "Hereditary Genius" (Macmillan, 1869).

"Watson, J. B., "Behaviourism" (Kegan Paul, 1931).

"Thurstone, L. L., "Primary Abilities" (Univ. Chicago Press, 1938). "Sholl, D. A., "The Organization of the Cerebral Cortex" (Methuen, 1956).

- Burt, C., and Howard, M., Brit. J. Statist. Psychol., 9, 95 (1956).

'Burt, C., Brit. J. Educ. Psychol, 13, 83 (1943).

- Floud, J. E., Halsey, H. E., and Martin, F. M., "Social Class and Educational Opportunity" (Heinemann, 1956).

\title{
COLONIAL RESEARCH
}

\section{5-56}

$\mathrm{U}$ NDER the title "Colonial Research 1955-56"* are collected the annual report of the Colonial Research Council, the eleventh annual reports of the Committee for Colonial Agricultural, Animal Health and Forestry Research and the Colonial Medical Research Committee, the ninth annual reports of the Colonial Economic Research Committee and the Colonial Committee for Pesticides Research (formerly the Colonial Insecticides, Fungicides and Herbicides Committee), the third annual report of the Colonial Products Council, the twelfth annual report of the Colonial Social Science Research Council, the first annual report of the Colonial Road Research Committee, the annual report of the Colonial Fisheries Advisory Committee on Fisheries Research, 1955-56, and the reports for 1955-56 of the Tsetse Fly Trypanosomiasis Committee and of the Director of the Anti-Locust Research Centre. There is also a section on research matters not covered by the reports of the specialist advisory bodies, which deals with building and housing research, the Falkland lslands Dependencies Survey, geodetic and topographic surveys, geological surveys (for which a further allocation of $£ 1,250,000$ has been made available to March 31, 1960, under the Colonial Development and Welfare Act, 1955, and whose staff of 205 geologists, geophysicists and chemists in twentyone territories receives valuable assistance from the universities of the United Kingdom and other members of the Commonwealth), the East African Industrial Research Board, meteorology and water pollution research.

The annual report of the Colonial Research Council, to which is appended a list of schemes approved for research grants under the Colonial Development and Welfare Acts, April 1, 1955, to March 31, 1956, deals with matters not covered by the reports of the specialist committees. It notes that the expenditure on research schemes for the year ended March 31, 1956 , was $£ 1,364,320$, compared with $£ 1,173,381$ the previous year and the average of $£ 1,600,000$ called for by the provision for 1955-60, and that 39 new appointments were made to the Research Branch during the year; but it does not supply the conspectus of the whole field that now seems desirable.

* Colonial Office. Colonial Research 1955-1956. Pp. 312. (Cmnd. 52.) (London: H.M. Stationery Office, 1957.) 108. net.
Besides lists of publications during the year, the various reports are now provided with a full list of contents.

The Committee for Colonial Agricultural, Animal Health and Forestry Research, which recommended grants for research totalling $£ 819,495$ during the year, is much exercised by the difficulty of finding and retaining good research scientists in overseas posts. Serious losses of young scientists with two to six years overseas experience continue. In September 1955 the three research schemes at the Imperial College of Tropical Agriculture, Trinidad, for work on cocoa, bananas and soils were combined and a Regional Research Centre was created under the Principal of the College as director of research. This Centre will in future embrace all appropriate fields of research. 'The West African Standing Advisory Committee for Agricultural Research has been established and met for the first time. Cocoa research, carried out chiefly at the West African Cacao Research Institute and the Imperial College of Tropical Agriculture, confirmed the close dependence of mineral nutrient uptake on the degree of shade, and demonstrated the connexion between the nitrogen status of a plant and its liability to attack by thrips. In West Africa, important information was gained on the tolerance of certain Iquitos strains of cacao to swollen shoot viruses, and preliminary tests indicated that BHC has a higher toxicity for capsids than DDT.

The South American maize rust disease which has caused much concern in the hot, humid parts of Africa continued to spread eastwards, being reported from Malaya, North Borneo, Siam and intervening islands in the Indian Ocean. Resistant varieties are being issued to growers in West Africa, where research is now directed to breeding for resistance to other pests and diseases. In the early stages of investigations in Kenya on coffee berry disease, the mercurial fungicide 'Verdasan' showed promise as a possible means of control. A pool of research workers on stored products has been established, based at the Pest Infestation Laboratory of the Department of Scientific and Industrial Research, and the Stored Products Research Sub-Committee was specially concerned with co-ordinating the work of the West African Stored Products Research Unit, the code of 
practice in the use of $\mathrm{BHC}$ and DDT, with the control of insect pests of groundnuts in the Gambia-where infestation of unshelled groundnuts by Caryedon fuscus can be reduced to a negligible level by application of 5 per cent of DDT or 1 per cent of 'Lindane' within the prescribed health limitations - and the use of insecticides on stored cocoa in West Africa. Veterinary investigations relate largely to the testing of biological preparations and other drugs and to the detailed study of well-known diseases in relation to local conditions and breeds of cattle. In East Africa outstanding findings relate to the considerable resistance to East Coast fever which exists in zebu animals from immune stock ; this resistance decreases with age, and colostral immunity plays little or no part in it. It is established that a solid immunity for at least a year follows recovery from an attack of East Coast fever, and that the fever may be suppressed by continuous oral administration of "Auro. fac', a by-product of the manufacture of aureomycin. It has also been observed that calves born of dams immune to rinderpest are susceptible before suckling but develop immunity one to two days after suckling; however, this colostral immunity declines fairly rapidly, disappearing in about six months. Use of 'Antrycide' has permitted large numbers of cattle to be held in areas of Kenya infested with tsetse fly, with low rates of infection by sleeping sickness.

At the Malayan Forest Research Institute excellent hardboards have been produced from mixtures of common Malayan woods and high-quality paper from pedi straw. Trials with tropical pines in the Caribbean have demonstrated the importance of small doses of phosphatic fertilizers in the early stages of growth, the response of the trees being remarkable in some cases. Much help was given to the Committee by research institutions in the United Kingdom, particularly the Agricultural Research Council and the Experimental Stations under its control. The Rothamsted Experimental Station, for example, completed a final comprehensive report on "The Responses of Sugar Cane to Fertilizers".

The Colonial Economic Research Committee's report is the briefest of the twelve. It records the completion of Prof. Gilbert Walker's monograph, "Nigerian Transport in 1950", and of Mr. G. A. Petch's report on the agricultural economy of Sierra Leone with special reference to the oil palm industry. Dr. A. R. Prest's fiseal survey of the British Caribbean is being prepared for publication in the Colonial Research Studies series, in which Mr. F. H. H. King's "Money in British East Africa" will also appear. Mr. D. T. Edwards, attached to the Institute of Social and Economic Research in the University College of the West Indies, is now completing the analysis of the economics of small farms in Jamaica, carried out in close association with the Jamaican Department of Agriculture; and work has been started on the national income inquiry in Tanganyika. The Royal University of Malta and the Durham Colleges are making a joint investigation into the agricultural economy of Malta. A grant of more than $£ 16,500$ was made to Makerere College to enable the East African Institute of Social Research to continue its work on industrial and labour economics in East Africa and to expand along lines suggested by the East Africa Royal Commission. The Economic Research Unit of the University College of the Gold Coast undertook an investigation into the problems of food supplies to the Sekondi-Takoradi area and neighbouring urban districts, to facilitate formulation of a feeder-road policy. The Scientific Council for Africa South of the Sahara is convening a meeting of economists in Nairobi to discuss the preparation and regular issue of a register of economic research in tropical Africa.

The annual report on fisheries research for 1955-56 comprises the reports of the individual Colonial fisheries research stations. The work of the InterTerritorial Fisheries Research Station at Jinja on Lake Victoria shows how the study of fisheries and of fish draws in as essential corollaries studies of the water they inhabit, of the bacteria and plants present in the water, of the soil and its chemical constituents and bacteria, and of the invertebrates, especially insects, which are probably the most important food of the fish in the Lake. While the content of biologically valuable electrolytes in the lakes of East Africa is much lower than might at first appear, plant nutrients occur in vast quantities in the deposits of organic matter on the lake bottom, and dried samples of this mud appear to offer potential supplements to the food of cattle, pigs and chickens, and the fertility of the lake would be increased if ways could be found to accelerate the decomposition of these deposits in situ. The research station now has a wide entomological programme. The East African Marine Fisheries Organization continues to study the big pelagic fishes of the western Indian Ocean, the principal bottom fishes (snappers and groupers), the oceanic circulation and variations in the layering of the waters with the changes of the monsoon. A study of the plankton has been undertaken, with a view of throwing light on the movement of the big pelagic fishes.

The Joint Northern Rhodesia-Nyasaland Freshwater Research Station started work at its new permanent headquarters at Samfya on Lake Bangweolo, but most of the year was devoted to a general survey of Lake Nyasa from an ecological point of view, with a more detailed study along the same lines of the lake littoral, and also of the Utaka, a group of species of cichlid fishes, which are one of the most important economic groups of the deep and rocky Northern Lake. At the West African Fisheries Research Institute important work has been done on the invertebrate bottom-fauna, the first results of which indicate that the biomass of the Sierra Leone benthos is considerably lower than that of comparable communities in European waters. The routine plankton survey of the Sierra Leone River estuary is nearing completion. At the Singapore Regional Fisheries Research Station the work on prawns, begun in the Singapore prawn ponds, has been extended into offshore waters and includes determination of the variety and distribution of species of Malayan Penacid prawns, identification of the more important economic species in the Singapore prawn ponds and in the fisheries of the Federation of Malaya, a study of the biological and other factors influencing them and an analysis of factors with a view of improving fishing techniques. Plankton research and hydrological investigations continued in the Singapore Straits. Construction of the Fish Culture Research Station, Batu Berendam, Malacca, is well advanced, and the Fisheries Research Unit in the University of Hong Kong continued routine hydro. graphic observations in waters around Hong Kong and obtained some promising results in research on the oyster fishery in Deep Bay. 
The eleventh annual report of the Colonial Medical Research Committee pays tribute to the services of Prof. P. A. Buxton, whose death was a grievous loss to the Committee. The digression into the field of the sickle-cell trait and sickle-cell anæmia noted last year has been continued, and the research on tuberculosis has now been extended to West Africa. Plans have matured for a research unit in West Africa on onchocerciasis under the scientific supervision of the West African Council, and two young zoologists are being recruited for comprehensive basic training in the malacological aspects of schistosomiasis before embarkirig on field investigations. A Leprosy SubCommittee has been appointed which has appointed a Laboratory Panel, both bodies comprising scientists whose investigations can contribute to the elucidation of problems confronting leprologists in chemotherapy, epidemiology, tissue culture, morbid histology, electron microscopy, immunology, bacterial resistance, etc., and five grants were made for leprosy research to aid investigators, both abroad and in British universities. A substantial grant was contributed towards a concerted research project to be initiated in Jordan, where a Trachoma Research Institute will be built and associated with a new ophthalmic hospital serving the large number of 'displaced persons' in that region among whom the disease is rife. The unit will be closely associated with virologists at the Institute of Ophthalmology, London, and the Lister Institute.

Laboratory studies on the effect of insecticides on Chrysops larvæ kept in trays full of mud indicate that both dieldrin granules and 5 per cent DDT emulsions will kill the larvæ, but at very high concentrations. A pilot scheme for the eradication of Bancroftian filariasis with diethylcarbamazine was initiated on Ukara Island in Lake Victoria; in Malaya administration of about six weekly or monthly doses each of $5 \mathrm{mgm}$. $/ \mathrm{kgm}$. of diethylcarbamazine citrate has been found to give promising results in the mass treatment of populations affected with Wuchereria malayi. Investigations on guineaworm at University College, Ibadan, were largely concerned with the location of the parasite within the body during the first two months after being fed to puppies. A comprehensive examination has been made of the anophelines in the Pare lowlands, East Africa, to establish a base-line from which the effect of residual house-spraying can be measured, and the degree of malarial infection in man over the whole area has been measured. The Malaria Control Pilot Project in Western Sokoto, Northern Nigeria, found a median lethal concentration for dieldrin of at least 2 per cent, in contrast with 0.25 per cent for $A$. gambiae from a Lagos colony or from unsprayed areas in Western Sokoto. Whereas malaria declined in the first half of the year, the decline was not maintained, especially toward the end of the rainy season. Epidemiological studies on yellow fever and the antigenically related but relatively innocuous virus, Uganda $S$, Zika and West Nile, have revealed problems of great complexity, while at the East African Virus Research Institute at Entebbe, Uganda, systematic studies on cycles of Rift Valley fever virus multiplication in the mouse and the pathogenic effects of the virus on the host were concluded.

The research project for the study of viruses in man, animals and arthropods in the Caribbean region had another most successful year, and a further extensive investigation is in progress at the University of Malaya to establish the position of polio. myelitis in Malaya. A comprehensive study of the feeding habits of tsetse flies indicated no significant variations in the feeding habits of $G$. morsitans and $G$. swynnertoni in ten different areas from which the blood-meals were obtained. In Tanganyika a unit detached from the Research Institute at Mwanza made a six months diet survey in the Taveta-Pare area as a contribution to the physiological assessment of the effects on the population of the attempted mitigation of malaria by residual house-spraying with dieldrin. At the Hot Climate Physiological Research Unit in Nigeria, studies of the effect of wind on reaction to heat and on sweat-gland fatigue continued, and the effect of climate on the performance of minor skilled tasks and the use of groundnut flour in human nutrition were also examined. The Tropical Metabolism Research Unit, Jamaica, continued its work on the gross composition of the tissues in malnutrition, and new evidence was obtained at the University College of the West Indies on why a fall in liver glycogen, now considered responsible for the 'vomiting sickness' of Jamaica, follows the administration of hypoglycin. The three main lines of research pursued on sickle-cell trait and sickle-cell anæmia were the chemistry of sickling; the conditions under which susceptible cells become sickled; and the genetics of hæmoglobin types. Therapeutic studies on leprosy in Nigeria have shown 'Avlosulfon Soluble' to be a suitable and convenient preparation for administration by injection, and diphenylthiourea has also given promising results in treating leprosy.

The ninth annual report of the Colonial Pesticides Research Committee refers to the disbanding of the Herbicides and Arboricides Sub-Committee and the formation of a new sub-committee on methods of application which will include in its terms of reference the application of liquid sprays, dusts, dispersible powders, aerosols, mists and fogs from the ground and from the air, incorporating the work formerly undertaken by the Aircraft Trials Sub-Committee. Arusha is being made the main centre for overseas Colonial Pesticides Research activity, by amalgamation of the Unit lately at Ilanga and by the later inclusion of other detached units. Work at Arusha has continued in an effort to establish the optimum conditions under which tsetse fly and mosquitoes may be killed, the Physics Section has devised a suitable installation for disseminating granular insecticides containing dieldrin by aircraft, and ground spraying experiments with arboricides and herbicides continued. The Biting Fly survey work in Uganda, the survey of filariasis vectors in Fiji and the Western Sokoto Malaria Control Pilot project also continued. The persistence of DDT, dieldrin and $\mathrm{BHC}$ water-dispersible powders on mud walls is found to be characterized by a rapid loss from the surface half-millimetre during the first two weeks after spraying. This loss of DDT and dieldrin is due primarily to diffusion into the wall and consequent inactivation biologically. Research into the control of Pseudotheraptus wayi, the chief cause of fall of coconuts in Zanzibar, continued.

At the Colonial Insecticide Research Unit, Porton, work on the sorption of insecticides by soils indicated that the rate of disappearance of insecticides from the sprayed surface of mud blocks is inversely proportional to the humidity; but once absorbed, the rate of diffusion of insecticide away from the surface is directly proportional to humidity, increased humidity enhancing the mobility of adsorbed insecticide. Work on residual deposits on vegetables 
proceeded, while that on the crystallization of insecticides from urea-formaldehyde resin films was completed. Studies of the cumulative effect of sublethal doses of insecticides suggest that house-flies can eliminate, metabolize or store in a harmless condition, depending on the insecticide, a proportion of that absorbed, providing the dosage is sufficiently low. Studies on olfactory stimulation of tsetse flies, on the pick-up of insecticides from surface deposits, and on the penetration of the insect integument by insecticides at the Imperial College Field Station, Silwood Park, continued, as well as the work at Rothamsted Experimental Station on the toxicity of DDT emulsion films and the persistence of DDT on foliage, and on the evaluation of new chemicals for controlling undesirable vegetation at the Agricultural Research Unit of Experimental Agronomy, Oxford. Attention is also directed to research being done in the Colonies without the assistance of the Committee.

The third annual report of the Colonial Products Council covers both the work of the Colonial Products Laboratory and research and development elsewhere carried out under the direction or with the assistance of the Council. Under an expanded programme of research on pyrethrum, to be co-ordinated by the newly-formed Pyrethrum Research Cormmittee (United Kingdom) in close liaison with a corresponding committee in East Africa, fundamental chemical investigations are to be made by the Colonial Products Laboratory and concomitant biological studies by the Rothamsted Experimental Station. The Laboratory handled 810 inquiries during the year, covering such products as essential oils, spices, copra, maize, sorghum, cassava starch, pineapples, citrus fruits, coir, hemp, paper-making materials, hides and wattle. The eighty investigations completed included examinations of sawdust and sawmill waste of slash pine from British Honduras; Cyprus sage oil; vetiver oil from British Guiana; ylang-ylang oil from Zanzibar ; cedarwood sawdust and oil from Kenya; Aleurites montana oil from Nyasaland; shea nut butter from West Africa; arrowroot starch from Antigua and Montserrat; kenaf fibre as a jute substitute, and grasses and reods from Northern Rhodesia as paper-making materials.

Experiments on controlled curing of cacao beans in 'micro-fermentaries' continued at the Colonial Microbiological Research Institute, Trinidad, where the action of polyphenol oxidase on catechol is also being examined and several high-yielding strains of Aspergillus terreus have been found for production of itaconic acid from molasses. 'The Sugar Technological Laboratory, Trinidad, continued investigations into the effect of drought on the properties of sugar cane juice. At the Forest Products Research Laboratory, Princes Risborough, satisfactory water resistance in boards from dense hardwoods, such as morabukea from British Guiana, was achieved without loss of strength by applying drying oils to the boards after pressing, followed by heat treatment, or by adding wax emulsion and synthetic resin to the pulp. At the University College of the West Indies conditions for growing the organisms producing monamycin in deep culture have been defined, studies on nonspecific acetylcholine antagonism at the Department of Pharmacology, University of Birmingham, were extended, and the structure of the two ketones obtained from cork has been elucidated at the Royal College of Science and Technology, Glasgow.
The first annual report of the Committee on Colonial Road Research notes that the Committee at its first meeting in June 1955 agreed on programmes of research concerned with pavement design ; drainage, erosion and moisture movement; bituminous surfacings; and machinery and labour problems. The Committee stresses the importance of an adequate number of materials engineers if the full benefits of research are to be obtained. Data collected by the Air Ministry on the movement and distribution of moisture in soils under airfields in tropical and sub-tropical areas are being analysed at the Road Research Laboratory, where a method developed for forecasting moisture conditions under pavements in Great Britain is the startingpoint of an investigation to provide a corresponding method applicable in other climates.

To the twelfth annual report of the Colonial Social Science Research Council are appended reports for 1955-56 from the East African Institute of Social Research, the West African Institute of Social and Economic Research now being wound up (to be replaced in Ghana by the recently formed Economic Research Unit), the Institute of Social and Economic Research, University College of the West Indies, the Rhodes-Livingstone Institute, the Educational Research Institute for Fiji and Western Pacific Territories and the Social Research Unit, University of Malaya. The most important new grants during the year were to Makerere College for the continuation of the East African Institute of Social Research $(£ 82,329)$; the Government of Northern Rhodesia for the central office and headquarters expenditure of the Rhodes-Livingstone Institute $(£ 32,770)$; University College, Ibadan, for the Department of History's Benim project $(£ 20,000)$; for the maintenance for a further year of the West African Institute of Social and Economic Research $(£ 7,483)$; a contribution towards a study of family attitudes in Jamaica undertaken by the Conservation Foundation $(£ 7,000)$; and to the Swaziland Government for a study of land tenure and land use $(£ 6,875)$. A third volume, on "The Non-Bantu Languages of North-east Africa", in the Handbook of African Languages of the International African Institute is in the press, and the Linguistic Survey of the Northern Bantu borderland, in which the Governments of Belgium, France, Nigeria and the Anglo-Egyptian Sudan elso cooperated, is being published in four volumes, of which Volume 1 has already appeared and Volumes 2 and 4 are in the press.

The report of the Tsetse Fly and Trypanosomiasis Committee for the year ended March 31, 1956, stresses the prospect of advances in the control of trypanosomiasis in domestic animals offered by the advent of a number of new trypanocidal drugs, trials of which in Africa were arranged. The Committee concluded that an important new phase had been reached in the control of bovine trypanosomiasis and recommended a conference of veterinarians from African administrations to stimulate progress and concerted effort. Present policy in tsetse research in East Africa gives priority to research on behaviour and physiology of Glossina, with an emphasis on laboratory studies; while at the West African Institute for 'Irypanosomiasis Research studies have been made on the mechanism of acquired drug resistance, using four syringe-passaged strains of $T$. rhodesiense, three of which had been made resistant to 
'Melarsen', 'Stilbamidine' and 'Butarsen', respectively. Experiments were also started on the possibility of forming suramin complexes with veterinary trypanocidal drugs, and basic research continued into the optimal conditions for rearing $G$. palpalis in the laboratory. In Northern Rhodesia studies were made of cross-resistance to drugs in trypanosomes occurring in cases treated with 'Dimidium', 'Ethidium' and Antrycide', and of the control of tsetses with insecticidal sprays, while in Uganda the Tsetse Control Department has obtained promising results in preliminary trials of 'Arkotine' for control of G. palpalis.

The report for $1955-56$ on locust research and control of the Director of the Anti-Locust Research
Centre, which received 1,171 reports from 42 territories in 1955, records further progress in the analysis of the seasonal development of desert locust plagues, and in the re-examination, in the light of recent information on swarm movements and behaviour, of the historical data on the ter-plague periods. The results suggest the possibility that some swarming populations occurring within the desert locust distribution area during the interplague periods may sometimes play an important part in the recrudescence of the plagues. In the locust laboratory the main emphasis has been on breeding Schistocerca. The Desert Locust Survey continued intensive investigations on the assessment and improvement of control methods, particularly aircraft spraying.

\section{OBITUARIES}

\section{Dr. G. B. Jeffery, F.R.S.}

GEORGE BARKer JEFFERY, director of the Institute of Education, University of London, who died on April 27, was born on May 9, 1891. He was educated at Wilson's Grammar School and went from there in 1909 to University College, London, where he rapidly made his reputation as a mathematician. $\mathrm{He}$ was appointed reader in mathematics in 1921 and Astor professor of mathematics in 1924; he was elected a Fellow of University College in 1916 and a Fellow of the Royal Society in 1926.

As this record implies, Jeffery's original work in mathematics began early (his first paper was read before the Royal Society in the month following his twenty-first birthday) and was distinguished. $\mathrm{He}$ covered a wide field in which the main subjects were the theory of relativity and (over a longer period) hydrodynamics and elasticity together with the theory of the relevant differential equations. His sustained interest in pure mathematics was evident, but the usual classification would assign most of his published work to applied mathematics. Much of his work was, however, concerned with exact solutions, and so was of particular value in fields where such solutions are rare and some form of approximation must often be accepted.

An inspiring teacher himself, Jeffery was interested in teaching in schools as well as in universities, in teaching overseas as well as at home ; this determined his choice of subject in various public addresses. In his presidential address to the London Mathematical Society (1937) his subject was the study of mathematies in modern universities. He said then that, if asked to say why he thought his own subject important, he might reply that "pure mathematics is a good subject because I like it", and suggested that all the implications of this answer should be fully thought out. In his presidential address in 1948 to the Mathematical Association on "Mathematics as an Educational Experience", he was concerned to defend mathematics as a school subject from "attack by the anti-intellectual forces that are rampant in our national educational thought". The imperfections in examinations were admitted, but "it would be idle to deny the stern discipline they effect by discriminating between sound knowledge and verbiage and between conscientious preparation and slacking".
It is perhaps natural that Jeffery, whose interests in mathematics were so wide, should have had wide interests outside, but it is astonishing that he should have found so much time and energy to devote to them. He was a skilled cabinet-maker, and excellent examples of his craft adorn University College, and no doubt other institutions with which he was concerned, and in later years he became a proficient silversmith. Since 1952 he had been dean of the College of Handicraft, and tribute has been paid to his enthusiasm by the master of the College, Mr. R. A. Butler.

In 1939 Jeffery acted as pro-provost for the section of University College that went to Bangor. He was occupied there with the difficult administrative problems of the war years as they affected the College and the University-and took part when occasion required in the rescue of parties of students in difficulties on Snowdon. He was appointed director of the Institute of Education shortly after the return in December 1944 of University College to London.

W. R. DEan

DR. G. B. JEFFERY first came into contact with the study of education and with the training of teachers when he was himself a student in 1911-12 at the old London Day Training College. It was there that he met his future wife; and it was there that he came under the influence of that great educator, Sir Percy Nunn. From the latter he acquired not only a deep interest in the philosophy of science and in the theory of education, but also an abiding faith in education as an instrument for social advance.

During the 'thirties, Prof. Jeffery was examiner in mathematics for several of the training colleges already associated with the University of London through the old Training Colleges Delegacy. Inevitably, his wisdom and his administrative gifts brought him into close contact with the running of that Delegacy : his counsel and advice were sought continually. Thus, when it became necessary, in 1945 , to work out the institutional mechanism needed to implement the McNair Report, it was to Jeffery that everyone turned. It was he who, more than anyone else, was responsible for drawing up a constitution and a set of regulations which are the charter of the London Area 'Training Organization. 